\title{
Перспективы использования дезинфектантов на основе глютарового альдегида и четвертичных аммониевых соединений для аэрозольной дезинфекции в птицеводстве
}

Кулица М.М., кандидат ветеринарных наук, доцент

ФГБОУ ВО «Московская государственная академия ветеринарной медицины и биотехнологии - МВА им. К.И. Скрябина»

Дорожкин В.И., доктор биологических наук, профессор, академик РАН, руководитель института

Всероссийский научно-исследовательский институт ветеринарной санитарии, гигиены и экологии (ВНИИВСгЭ) - филиал ФГБНУ ФНЦ «ВИЭВ им. К.И. Скрябина и Я.Р. Коваленко» РАН

\begin{abstract}
Аннотаиия: Дано описание и прибедены результаты исследований по разработке режимоб и технологии аэрозольной дезинсрекиии 6 помещениях для содержания сельскохозяйственных жиботных и птицы. Показана высокая эффектибность и надежность применяемого с этой иелью отечественного универсального дезинфииииующего средства широкого спектра действия на основе глютарового альдегида и четвертичных аммониебых соединений. Дано описание проблематики некачественной дезинфекции 6 птицебодстве: бозможные потери предприятия от этого, вред некоторых применяемых средств, способы протибомикробной обработки участков птицебодческого предприятия. Показана бысокая эфрфектибность и надежность 6 птицебодстве технологии аэрозольной обработки с использованием отечественного универсального дезсредства; приведена информация об исследованиях по данному препарату, диапазону его применения и перспективах использования.
\end{abstract}

Ключебые слоба: аэрозольная дезинфекция, птицебодство, инкубационное яйцо, инкубатор, бройлер, несуика, птичник, альдегиды, микроорганизмы, биобезопасность.

До настоящего времени для дезинфекции обьектов ветеринарно-санитарного надзора создано еще недостаточно экологически безопасных, высокоэффективных и дешевых дезинфицирующих средств, позволяющих проводить аэрозольную дезинфекцию поверхностей в животноводческих и птицеводческих помещениях, оборудования и других объектов [1].

Все ветеринарные специалисты очень четко понимают необходимость проведения не только вынужденной, но и профилактической дезинфекции на животноводческом предприятии и особенно на птицефабрике. Это обусловлено тем, что экономические потери при бактериальном загрязнении птичника могут быть катастрофическими для предприятия. В основном, уровень загрязненности определяют по постоянным «гостям» в птицеводстве E. coli, протею, сальмонелле, т.к. они являются основными источниками порчи продукции птицеводства [2,7]. По данным [3], современные животноводческие и птицеводческие комплексы становятся источниками загрязнения среды биоаэрозолями, пылью и вредными газами, которые ежедневно выбрасываются вентиляционной системой в атмосферу; биоаэрозоль в воздухе птични- ков может содержать представителей родов Bacillus, Pseudomonas, Pasteurella, Corinebacterium, Salmonella, Enterobacter, Leptospira, Brucella, Haemofilus, Vibrio, Yersinia, Mycoplasma, Streptococсиз и др.

Очень часто экономическая эффрективность птицеводческого хозяйства достигается за счет высокой концентрации и плотности размещения птицы на ограниченных площадях. Однако это приводит к тому, что количество микроорганизмов в помещениях резко возрастает, и особенно растет количество патогенной микрофлоры. Высокая плотность поголовья вызывает повышенную чув- 
ствительность животных и птицы к патогенной микрофлоре, при этом значительно возрастает вероятность массовой вспышки инфекционных заболеваний [13]. Концентрация микроорганизмов в воздухе - важный показатель эпизоотического состояния птицефабрики, поскольку распространение патогенной микрофлоры воздушным путем - одно из самых быстрых, что создает опасность возникновения массовых заболеваний птицы. В воздухе птицефабрик выявлено свыше 30 видов микроорганизмов, в том числе 13 видов грибов с преобладанием родов Aspergillus и Penicillium [3].

Или другой пример: при изучении видового состава микрофлоры в корпусах для молодняка крупного рогатого скота были выделены патогенные штаммы Staph. aureus, Str. faecalis, E. coli, Candida spp., Aspergillus spp. [13]. Bce эти микроорганизмы - опасные патогены, особенно для животных и людей с ослабленным иммунитетом. Высокая загруженность комплексов, технологические нарушения приводят к поддержанию и распространению различных заболеваний, снижающих сохранность и продуктивность поголовья.

При превышении ПДК микроорганизмов в воздухе у цыплят снижается среднесуточный прирост живой массы, сохранность, а также отмечается достоверное снижение гуморальных факторов естественной резистентности [3]. Актуальной проблемой в птицеводстве остаются острые кишечные инфекции, самые распространенные из которых - колибактериоз и сальмонеллез. При недостаточной и некачественной дезинфекции птицеводческих по- мещений в профилактических перерывах происходит размножение и накопление патогенной микрофлоры в воздухе, что приводит к заражению вновь размещенного поголовья. Таким образом, современное интенсивное птицеводство представляет потенциальный риск для здоровья как птицы, так и людей, работающих на птицефабриках. Можно ли решить эту проблему?

Основной источник загрязнения воздуха в птичниках - сама птица и мучнистые корма. Птицы выделяют микроорганизмы через верхние дыхательные пути при кашле (капельная инфекция), а также с испражнениями, которые затем высыхают и суспендируются в воздухе в виде пыли. Сыпучие корма в момент их раздачи также загрязняют воздух и создают пыль растительного происхождения. В таких условиях птица становится более чувствительной к воздействию патогенных микроорганизмов, отмечается снижение сохранности и среднесуточного прироста живой массы. При этом постоянно присутствует вероятность вспышки массового инфекционного заболевания с поражением всего поголовья [14]. Следовательно, к обязательным условиям успешного функционирования предприятий птицеводства относится и такое мероприятие, как дезинфекция.

Противоэпизоотические мероприятия в птицеводстве - это не только предотвращение заноса и распространения возбудителей заболеваний, но и система контроля, осуществляемая путем применения препаратов, обладающих лечебно-профилактическим действием, дезинфицирующей способностью и широким спектром антимикробной активности [3,13]. Такие препараты должны обладать быстрым действием при минимальной концентрации, не терять свои свойства при хранении и быть по возможности нетоксичными и безвредными [1 1, 15].

До настоящего времени в РФ повсеместно для дезинфекции применяется формалин, который закупается тоннами; однако руководители предприятий должны четко понимать его вред для здоровья человека, чтобы не превратить птицефабрику в полигон сильнодействующих ядовитых веществ. В большинстве стран мира его использование запрещено в целях предупреждения развития раковых болезней среди сотрудников, поскольку формалин является сильнейшим канцерогеном $[4,5]$.

Современные средства для дезинфекции значительно безопаснее для человека, и в птицеводстве их применение будет эффективно для влажной и аэрозольной обработки. Одним из таких дезинфекционных средств, отвечающих требованиям безопасности, является отечественный препарат на основе глютарового альдегида (АГ) и четвертичных аммониевых соединений (ЧАС) $[9,16,17]$. Он представляет собой прозрачную жидкость от светложелтого до красно-коричневого цвета, с характерным запахом, вспенивающуюся при встряхивании. В качестве действующего вещества он содержит четвертичные аммониевые соединения и глутаровый альдегид, а в качестве вспомогательных компонентов - НПАВ, изопропиловый спирт и др.

Самый эффективный способ дезинфекции в птицеводстве - 
аэрозольная обработка. Аэрозоль полностью заполняет все пространство помещения, включая поверхности ограждающих конструкций, оборудование, все щели и труднодоступные места. Данная технология характеризуется экономией трудозатрат и оптимальным расходованием дезраствора [6]. Такая дезинфекция позволяет полностью исключить распространение микроорганизмов и вирусов при условии соблюдения требований инструкции по применению используемого дезинфектанта.

Это не просто заявление, это доказанный факт, что подтверждено отчетами ГНУ ВНИИВВиМ (2015) и ФГБНУ ВНИИВСГЭ (2016), а также многочисленными отзывами из хозяйств, в которых данный препарат нашел применение [18].

С целью определения возможности использования препарата для аэрозольной дезинфекции, с перспективой применения на объектах птицеводства [16], проведены исследования по разработке режимов и технологии аэрозольной дезинфекции тестповерхностей и поверхностей помещений, в соответствии с требованиями Методических указаний «О порядке испытания новых дезинфицирующих средств для ветеринарной практики» (Утв. ГУВ Госагропрома СССР 07.01.1987) и «Правилами проведения дезинфекции и дезинвазии объектов государственного ветеринарного надзора (М., 2002).

Опыты, в количестве 35, проведены в условиях герметизированных камер на тест-объектах из дерева, бетона и железа, контаминированных микроорганизмами 1-4 групп устойчивости к химическим средствам; в помеще- ниях вивария для содержания лабораторных и сельскохозяйственных животных, а затем - на птицефабриках Ставропольского и Краснодарского краев. Проведена комиссионная проверка разработанных режимов и технологии аэрозольной дезинфекции этим средством.

Установлено, что аэрозоли средства в концентрации 5\% (по препарату) при норме расхода 30 мл/м $\mathrm{M}^{3}$ помещения и экспозиции 6 ч инактивируют кишечную палочку (1-я группа устойчивости) на тест-объектах из дерева и железа с белковой защитой, а через 24 ч - на тест-обьектах из бетона; золотистый стафилококк (2-я группа устойчивости) - в 8\% концентрации при экспозиции 6 ч, а микобактерии (3-я группа устойчивости) - в той же концентрации при экспозиции 24 ч. Споры Вас. cereus (4-я группа устойчивости) инактивируются $10 \%$ раствором за 24 ч. Норма расхода во всех случаях остается неизменной - 30 мл/ $\mathrm{M}^{3}$.

Таким образом, в результате проведенных исследований разработаны высокоэффективные режимы и технология аэрозольного применения препарата на гладких и шероховатых поверхностях с белковой защитой, в том числе непосредственно в условиях промышленного производства продукции птицеводства [8].

В то же время, рекомендованные соответствующими инструкциями режимы применения зарубежного аналога данного препарата в концентрации 20-25\% из расчета 1 л концентрата сред-

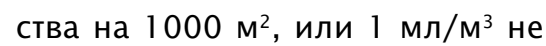
обеспечивают надежную дезинфекцию поверхностей с белковой защитой, но в форме аэрозо- лей - уменьшают бактериальную контаминацию воздуха. Это показано в сравнительных испытаниях данных препаратов [9-12].

Любопытные данные о профилактике распространения на птицеводческих предприятиях возбудителя гриппа птиц приведены в статье [17], где в сравнительном аспекте показаны результаты тестирования на санитарно-показательном микроорганизме 2-й группы устойчивости - золотистом стафилококке (штамм 209-Р) - ряда дезинфицирующих средств, как давно используемых, так и разработанных недавно. Авторами установлено, что все испытанные препараты являются эффективными средствами для влажной и аэрозольной дезинфекции объектов ветеринарного надзора при болезнях, вызванных возбудителями 2-й группы устойчивости (к которым относится и вирус гриппа птиц).

Разработанные эффективные режимы и технология аэрозольной дезинфекции объектов ветеринарного надзора отечественным средством были проверены комиссионно в лабораторных и производственных опытах, рассмотрены рецензентами и Ученым советом ФГБНУ ВНИИВСГЭ, и одобрены методической комиссией «Ветеринарная санитария, гигиена и экология» секции «Зоотехния и ветеринария» Отделения сельскохозяйственных наук РАН (протокол №2 от $01.11 .2016)$.

Данная технология [8] была утверждена Председателем методической комиссии «Ветеринарная санитария, гигиена и экология» секции «Зоотехния и ветеринария» Отделения сельскохозяйственных наук РАН 15.11.2016. 


\section{Литература}

1. Гармаев М.Ц. Разработка новых дезинфицирующих средств в системе противоэпизоотических мероприятий: дис. ... д-ра биол. наук:. - Казань, 2014. - 230 c.

2. Мартынов Г.Н. Фармако-токсикология дезинфектантов на основе четвертичных аммониевых соединений и их применение в птицеводстве: дис. ... д-ра вет. наук. - Белгород, 2002. $307 \mathrm{c}$.

3. Фисинин В.И., Трухачев В.И., Салеева И.П. [и др.] Микробиологические риски в промышленном птицеводстве и животноводстве // С.-х. биология 2018. - Т. 53. - №5 - С. 1120-1130.

4. Гершун В.И. [и др.] Ветеринарная гигиена. - Костанай, 2005.

5. Попов Н.И. Дезинфекция объектов ветеринарного надзора бактерицидными пенами: дис. ... д-ра вет. наук. М., 2005. - 501 c.

6. Аэрозоли в профилактике инфекционных заболеваний сельскохозяйственных животных / Ю.И. Боченин [и др.] // Ветеринарный консультант. 2004. - №23-24. - С. 10-18.

7. Сидорова А. Микробная загрязненность воздуха в птичнике // Птицеводство. - 2008. - №6. - С. 30.
8. Технология аэрозольной дезинфекции объектов ветеринарного надзора препаратом Абалдез ${ }^{\circ}$ : Утв. РАН 15.11.2016. - М., 2016. - 13 c.

9. Дорожкин В.И., Прокопенко А.А., Морозов В.Ю., Дронфорт М.И. Препараты для дезинфекции обьектов ветеринарного надзора // Птицеводство. 2017. - №5. - С. 50-53.

10. Сравнительные испытания эффективности препаратов Абалдез и Вироцид на тест-объектах в лабораторных опытах: Приложение к Отчету ВНИИВСГЭ №1н/16. - М., 2016. - 6 с.

11. Краснобаев Ю.В., Краснобаева О.А. Вироцид в присутствии животных - новые аспекты безопасности // Ветеринария. - 2011. - №3. - С. 15-17. 12. Краснобаев Ю.В. Вироцид: обработка в присутствии птицы // Птицеводство. - 2010. - №10. - С. 55-56.

13. Морозов В.Ю., Сытник Д.А., Агарков А.В. Источники контаминации воздуха закрытых помещений и видовой состав микрофлоры // Вестник АПК Ставрополья. - 2016. - №1. - С. 73-76.

14. Крайнов Я. В. Санитарно-микробиологический мониторинг воздуха птичника / Я.В. Крайнов, Д.В. Федерякина, П.А. Паршин // Сб. тр. конф. «Ветеринарно-санитарные аспекты качества и безопасности сельскохозяйственной продукции». - Воронеж, 2015. - С.44-46.

15. Аминева Э.М. Эффрективность дезинфицирующих средств в отношении представителей семейства Enterobacteriaceae в условиях птицеводческого предприятия / Э.М. Аминева, Н.Ю. Арсентьева // Вестник Челябинского гос. ун-та. - 2013. - №7. С. 53-54.

16. Салеева И.П. [и др.] Аэрозольная дезинфекция птицеводческих объектов // Птица и птицепродукты. 2018. - №5. - С. 18-21.

17. Дорожкин В.И Экологически безопасные дезинфицирующие препараты для обработки помещений и оборудования, контаминированных микроорганизмами 2-й группы устойчивости / В.И Дорожкин, Н.И. Попов, А.А. Прокопенко, Ю.И. Боченин // Ветеринария. - 2018. - №4. - С. 50-52.

18. Сайт www.abaldez.com [Электронный ресурс]

\section{Для контакта с авторами:}

Кулица Михаил Михайлович

E-mail: kulitsa02@mail.ru

Дорожкин Василий Иванович

E-mail: vniivshe@mail.ru

\title{
Prospects for the Use of Disinfectants Based on Glutaraldehyde and Quaternary Ammonium Compounds for Aerosol Disinfection in Poultry Farming
}

\author{
Kulitsa M.M.', Dorozhkin V.I. ${ }^{2}$ \\ 'Moscow State Academy of Veterinary Medicine and Biotechnology - MVA of K.I. Skryabin; \\ ${ }^{2}$ Federal Scientific Center "All-Russian Institute of Experimental Veterinary" \\ of K.I. Skryabin and Y.R. Kovalenko" of Russian Academy of Sciences
}

Summary: The research aimed at the development of regimes and technology of aerosol disinfection for animal and poultry producing enterprises is reviewed. The research confirmed high efficiency and reliability of universal disinfectant based on glutaraldehyde and quaternary ammonium compounds developed in Russia and featuring a wide range of antimicrobial activities. The problems related to improper disinfection on poultry farms and resulting financial losses; the harmful effects of certain disinfectants; the methods of antimicrobial treatment of different sites of poultry farms are briefly reviewed. The technology of the aerosol disinfection with the Russian disinfectant was found highly effective for poultry farms; the results of the studies on poultry, the efficiency and prospects of this technology are discussed.

Keywords: aerosol disinfection, poultry farming, hatching eggs, incubator, broiler, laying hen, poultry house, aldehydes, microorganisms, biosafety. 